\title{
Profil Peripheral Blood Mononuclear Cells (PBMC) Pasien dengan Berbagai Usia Menggunakan Flow Cytometry di Klinik Hayandra
}

\author{
Masayu Nadhira ${ }^{*}$, Riris L. Puspitasari ${ }^{1}$, Karina F. Moegni ${ }^{2}$, Imam Rosadi $^{2}$, Iis Rosliana ${ }^{2}$ \\ ${ }^{1}$ Program Studi Biologi (Bioteknologi), Fakultas Sains dan Teknologi, Universitas Al-Azhar Indonesia, Jl. \\ Sisingamangaraja, Jakarta 12110 \\ ${ }^{2}$ Klinik Hayandra, Yayasan Hayandra Peduli, Jl. Kramat 6, Jakarta 10430
}

"Penulis untuk Korespondensi: msy.nadhira@gmail.com

\begin{abstract}
Abstrak - Profil Peripheral Blood Mononuclear Cells (PBMC) setiap orang dapat berbeda-beda. Salah satu faktor yang diduga mempengaruhi adanya perbedaan tersebut adalah usia. Manusia berusia lanjut lebih mudah terserang penyakit karena terjadinya penurunan fungsi dan jumlah sel imun. Oleh karena itu, perlu dilakukan analisis komposisi PBMC untuk mengetahui profil PBMC seseorang berdasarkan usia, sehingga dapat diketahui jumlah sel imun dalam tubuh manusia. Tujuan dari penelitian ini adalah untuk menganalisis profil PBMC pasien dengan berbagai usia di Klinik Hayandra menggunakan flow cytometry. Manfaat dilakukannya kegiatan penelitian ini adalah diperolehnya informasi mengenai profil PBMC pasien di Klinik Hayandra dan kaitannya dengan usia. Metode yang dilakukan diantaranya adalah isolasi PBMC, proses pewarnaan PBMC, dan penentuan populasi sel menggunakan flow cytometry. Cluster of Differentiation (CD) yang digunakan pada kegiatan penelitian ini diantaranya adalah CD3, CD19, CD8, CD56, dan CD314 atau disebut juga NKG2D (Natural Killer Group 2 member $D$ ). Hasil yang diperoleh pada kegiatan penelitian ini adalah ditemukannya korelasi negatif yang bermakna antara persentase jumlah sel limfosit $T$ sitotoksik (CD3+/CD8+) dengan usia dan ditemukannya korelasi positif yang bermakna antara persentase jumlah sel NKT (CD3+/CD56+) dengan usia. Dengan demikian usia pasien dapat mempengaruhi jumlah sel imun pasien.
\end{abstract}

Abstract - Peripheral Blood Mononuclear Cells (PBMC) profiles of each person can different. One of the factors that allegedly affects the difference is age. Elderly human are more susceptible attacked disease due to decreased function and number of immune cells. Therefore, it is necessary to do analyze PBMC composition to know the PBMC profile of person, so that can be known the number of immune cells in the human body. The purpose of this research is to analyze the PBMC profile of patients with various ages in the Hayandra Clinic using flow cytometry. The benefit of doing this practical work is obtained information about the PBMC profile of patients in the Hayandra Clinic and its relation to age. Methods which are conducted among others are PBMC isolation, PBMC staining process, running flow cytometry, and determination of cell population. Cluster of Differentiation (CD) used in this practical work among others are CD3, CD19, CD8, CD56, and CD314 or also called NKG2D (Natural Killer Group 2 member D). The results obtained in this research were the found of significant negative correlation between percentage of cytotoxic $\mathrm{T}$ cell lymphocytes numbers $(\mathrm{CD3}+/ \mathrm{CD8}+)$ with age and found a significant positive correlation between percentage of NKT cell numbers (CD3+/CD56+) with age. So it can be concluded that the patient's age can affect the number of the patient immune cells.

Keywords - Peripheral Blood Mononuclear Cells (PBMC), flow cytometry, age, Cluster of Differentiation (CD)

\section{PENDAHULUAN}

$\mathrm{B}$ ertambahnya usia dan menjadi tua merupakan tahapan hidup yang akan dialami oleh setiap makhluk hidup. Tubuh manusia berusia lanjut lebih mudah terserang penyakit karena terjadinya penurunan fungsi dan jumlah sel imun yang menyebabkan kemampuan sistem imun dalam melawan infeksi menjadi berkurang [1]. Dalam memahami sistem imun manusia, dapat dilakukan analisis komposisi Peripheral Blood Mononuclear Cells (PBMC). Analisis PBMC akan menghasilkan 
profil jenis sel imun yang dimiliki oleh seseorang. PBMC adalah sel darah yang memiliki inti bulat, terdiri atas limfosit dan monosit [2] [3]. Analisis PBMC penting untuk mengidentifikasi penanda sel imun dan mengetahui jumlah sel imun yang terdapat dalam tubuh manusia [4].

Profil PBMC dapat diketahui dengan menggunakan metode imunohistokimia (immunohistochemistry). Imunohistokimia adalah suatu metode untuk mendeteksi keberadaan molekul atau berbagai macam komponen yang terdapat di dalam sel atau jaringan dengan menggunakan prinsip reaksi antara antigen dengan antibodi [5]. Namun, penggunaan imunohistokimia ini memiliki berbagai kelemahan, yaitu terbatasnya ketersediaan antibodi monoklonal yang dapat digunakan untuk pewarnaan histologis, tidak dapat dilakukannya pewarnaan ganda pada sel yang sama, tidak dapat dilakukan pengukuran persentase sel untuk pemantauan terapeutik, dan waktu penyelesaiannya yang cukup lama. Oleh karena itu, digunakan alternatif lain untuk memperoleh profil PBMC, yaitu dengan menggunakan flow cytometry [6].

Flow cytometry adalah teknik yang dapat digunakan untuk membedakan sel berdasarkan penyebaran sinar [7] yang akan ditangkap oleh detektor [8]. Detektor dapat mengidentifikasi berbagai antigen permukaan sel yang dianalisis. Hasil identifikasi yang ditampilkan berupa scattergram. Hal ini menjadikan flow cytometry sebagai teknik yang tepat untuk menganalisis populasi sel yang kompleks dalam waktu yang singkat [9]. Keunggulan lain dari flow cytometry adalah memiliki tingkat sensitivitas yang tinggi terhadap sel, sehingga hasil yang diperoleh lebih akurat. Flow cytometry dinilai lebih efektif dan efisien karena waktu penyelesaiannya cepat, melimpahnya ketersediaan antibodi monoklonal yang dapat digunakan, pewarnaan ganda pada sel yang sama dapat dilakukan dengan 5 hingga 8 warna, dan dapat mengukur beberapa parameter secara bersamaan [8] [6]. Sel yang akan dianalisis menggunakan flow cytometry terlebih dahulu diberi pewarnaan menggunakan antigen permukaan sel yang sangat spesifik, yaitu berupa Cluster of Differentiation (CD) dengan fluorokrom terkonjugasi [10]. CD adalah sistem nomenklatur untuk antigen permukaan sel manusia, yang ditandai dengan antibodi monoklonal [11]. CD yang digunakan pada kegiatan penelitian ini diantaranya adalah CD3, CD19, CD8, CD56, dan CD314 atau disebut juga NKG2D (Natural Killer Group 2 member D). CD3 merupakan penanda sel limfosit T, CD8 merupakan penanda sel limfosit $\mathrm{T}$ sitotoksik [12], CD19 merupakan penanda sel limfosit B [13], CD56 merupakan penanda sel Natural Killer (NK) [14], dan NKG2D merupakan penanda sel Natural Killer (NK) yang aktif [15].

Profil PBMC setiap orang dapat berbeda-beda. Salah satu faktor yang diduga mempengaruhi adanya perbedaan tersebut adalah usia. [16] dalam penelitiannya menemukan bahwa persentase sel Invariant Natural Killer T (iNKT) berkurang seiring dengan bertambahnya usia. Berdasarkan hal tersebut, maka perlu diketahui korelasi antara persentase sel imun lainnya, yaitu sel limfosit $\mathrm{T}$, sel limfosit T sitotoksik, sel NK, sel NKT, dan sel NKT yang aktif dengan usia.

Kegiatan penelitian ini dilakukan dengan tujuan untuk menganalisis profil PBMC pasien dengan berbagai usia di Klinik Hayandra menggunakan flow cytometry. Manfaat dilakukannya kegiatan penelitian ini adalah diperolehnya informasi mengenai profil PBMC pasien di Klinik Hayandra dan kaitannya dengan usia.

\section{TINJAUAN PUSTAKA}

\section{Peripheral Blood Mononuclear Cells (PBMC)}

Darah terdiri atas plasma dan sel-sel darah. Plasma adalah cairan darah yang mengandung haptoglobin, transferin, feritin, seruloplasmin, kinina, enzim, polipeptida, glukosa, asam amino, lipid, berbagai mineral, metabolit, hormon dan vitamin-vitamin, sedangkan sel-sel darah terdiri atas trombosit, eritrosit, dan leukosit (basofil, eosinofil, neutrofil, limfosit, dan monosit). PBMC merupakan sel darah yang memiliki inti bulat [2] dan merupakan populasi sel yang heterogen. PBMC terdiri atas sel limfosit B $( \pm 15 \%)$, sel limfosit T (70-90\%), sel NK $( \pm 10 \%)$, dan sel monosit $( \pm 5 \%)$ [17]. Limfosit dan monosit berperan penting dalam melawan infeksi, sel kanker, dan zat asing lainnya [18].

PBMC dapat diisolasi dari darah menggunakan Ficoll-Paque. Ficoll-Paque adalah hidrofilik polisakarida yang dapat memisahkan sel darah merah, plasma dan PBMC. PBMC terletak di bawah lapisan plasma [2]. PBMC akan membentuk populasi sel yang tetap berada pada fraksi kerapatan rendah (fraksi atas), sedangkan sel darah merah akan berada pada fraksi bawah dan memiliki kerapatan yang lebih tinggi [19]. 
Limfosit adalah sel darah putih yang terdiri atas sel T, sel B, dan sel NK [20]. Gambar 1 memperlihatkan mekanisme kerja sel imun yang melibatkan sel T, sel $\mathrm{B}$, dan antibodi. Sel $\mathrm{T}$ adalah sel yang memiliki reseptor sel berbentuk $\mathrm{T}$ pada permukaan sel yang mampu mengenali antigen dan mengikatnya.

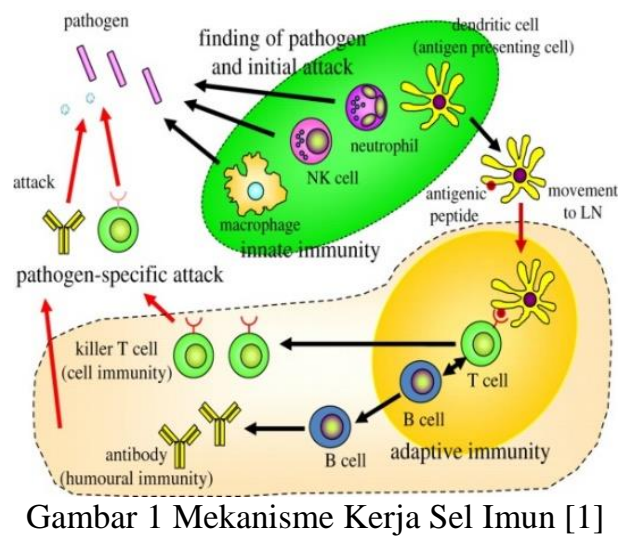

Sel $\mathrm{T}$ dapat dibagi lagi menjadi berbagai macam sel $\mathrm{T}$, yaitu sel limfosit $\mathrm{T}$, sel limfosit $\mathrm{T}$ sitotoksik, dan sel T pembantu ( $T$ helper). Sel B adalah sel yang ditandai oleh reseptor sel B yang dapat menyerang antigen asing yang beredar di dalam aliran darah. Sel NK adalah sel sitotoksik, yaitu sel yang dapat membunuh sel lain. Sel NK dapat mengenali zat asing lalu membunuh zat asing tersebut sebelum zat asing itu menimbulkan bahaya bagi tubuh. Sel NK memiliki ukuran sel yang lebih besar daripada sel $\mathrm{T}$ dan sel B. Sel NK memegang peran sebagai garis pertahanan pertama melawan patogen dan sel tumor [18].

\section{Flow cytometry}

Flow cytometry merupakan suatu teknik yang dapat digunakan untuk menganalisis jenis-jenis sel yang terdapat pada suatu populasi sel yang heterogen secara akurat dan cepat [21] [22]. Flow cytometry dapat digunakan untuk membedakan sel atau partikel berdasarkan penyebaran sinar serta untuk menghitung persentase subpopulasi sel. Prinsip kerja dari flow cytometry adalah memanfaatkan penyebaran sinar dari sel yang dialirkan satu persatu melalui sinar laser. Sel tersebut kemudian diamplifikasi dan dikonversi menjadi sinyal digital. Hasilnya tertera pada layar monitor berupa scattergram dan two parameter dot plots. Selain itu, dapat juga dilakukan analisis menggunakan teknik fluoresensi yang dihasilkan dari sel yang dilabeli dengan fluorescence, yaitu sel terlebih dahulu diberi pewarna/fluorescence, sehingga hasil yang muncul pada layar monitor adalah berupa scattergram yang berwarna sesuai dengan pewarna/fluorescence yang dilabeli ke sel tersebut [7]. Keuntungan dari flow cytometry yaitu memiliki tingkat efisiensi dan sensitivitas yang tinggi terhadap sel [8].

\section{METODE PENELITIAN}

Kegiatan penelitian dimulai pada bulan Februari 2018 sampai dengan bulan Maret 2018 di Klinik Hayandra.

\section{Isolasi PBMC}

Tahapan yang dilakukan pada isolasi PBMC adalah: Sebanyak $1 \mathrm{ml}$ darah pasien dimasukkan ke dalam tabung lithium heparin, lalu darah diencerkan dengan $1 \mathrm{ml}$ HBSS steril (perbandingan darah dengan HBSS adalah 1:1). Kemudian, larutan tersebut dihomogenkan. Setelah itu, tabung baru yang masih kosong disiapkan, Ficoll-Paque sebanyak $1 \mathrm{ml}$ dimasukkan ke dalam tabung baru tersebut. Darah yang sudah dilarutkan dimasukkan ke dalam tabung tersebut secara perlahan melalui dinding tabung agar darah tidak tercampur dengan Ficoll-Paque. Selanjutnya, dilakukan sentrifugasi dengan kecepatan $2500 \mathrm{rpm}$ selama 10 menit, dengan akselerasi sebesar $7 \mathrm{rpm}$ dan deselerasi sebesar $1 \mathrm{rpm}$. Setelah disentrifugasi, terbentuk 3 lapisan pada tabung tersebut, yaitu darah berada pada lapisan bawah, Ficoll-Paque berada pada lapisan tengah, dan plasma berada pada lapisan atas. PBMC berada diantara lapisan plasma dan lapisan Ficoll-Paque. Kemudian, plasma yang berada pada lapisan atas dibuang, sehingga lapisan PBMC dapat diambil. Setelah itu, PBMC diambil dan dimasukkan ke dalam tabung yang baru. PBMC dicuci dengan ditambahkan HBSS hingga volume tabung mencapai $5 \mathrm{ml}$. Selanjutnya, dilakukan sentrifugasi dengan kecepatan 900 rpm selama 10 menit, dengan akselerasi dan deselerasi masing-masing $7 \mathrm{rpm}$. Lalu, larutan diresuspensi dan kemudian disentrifugasi kembali dengan kecepatan 800 rpm selama 10 menit, sehingga diperoleh PBMC untuk analisis selanjutnya.

\section{Proses Pewarnaan PBMC}

PBMC yang telah didapatkan selanjutnya dipindahkan ke dalam 3 tabung polystyrene round bottom yang berbeda dengan volume yang sama. Lalu, tabung ke-1 diberi nama "kontrol negatif", tabung ke-2 diberi nama "kontrol isotype", dan tabung ke-3 diberi nama "sampel". Seluruh tabung disentrifugasi dengan kecepatan $1200 \mathrm{rpm}$. Kemudian supernatan dibuang dan ditambahkan running buffer sebanyak $1 \mathrm{ml}$. Setelah itu, larutan dihomogenkan. Selanjutnya, sampel direaksikan dengan larutan penanda CD3-VioBlue, CD19-FITC, 
CD56-PE, dan NKG2D-APC masing-masing sebanyak $10 \mu \mathrm{l}$ sesuai dengan instruksi dari manufaktur. Sampel juga direaksikan dengan larutan penanda CD8-PerCP-Vio700 sebanyak $2 \mu 1$. Kemudian, sel pada tabung kontrol isotype direaksikan dengan larutan penanda REA ControlFITC, REA Control-PE, Mouse IgG2a-VioBlue, dan Mouse IgG1-APC. Sel pada tabung yang tidak diberikan larutan penanda digunakan sebagai kontrol negatif. Kontrol negatif digunakan untuk menentukan populasi sel yang negatif, sedangkan kontrol isotype digunakan untuk membuktikan bahwa sel yang positif bukan karena adanya interaksi non spesifik antara $\mathrm{Fc}$ reseptor dengan antibodi pada sel.

\section{Penentuan Populasi Sel}

Berdasarkan plot Side Scatter (SSC) dan Forward Scatter (FSC), dapat ditentukan populasi sel yang akan dianalisis. Gambar 4 memperlihatkan populasi sel yang diinginkan berwarna hijau dan biru serta bebas dari daerah debris yang berada di sebelah kiri bawah.

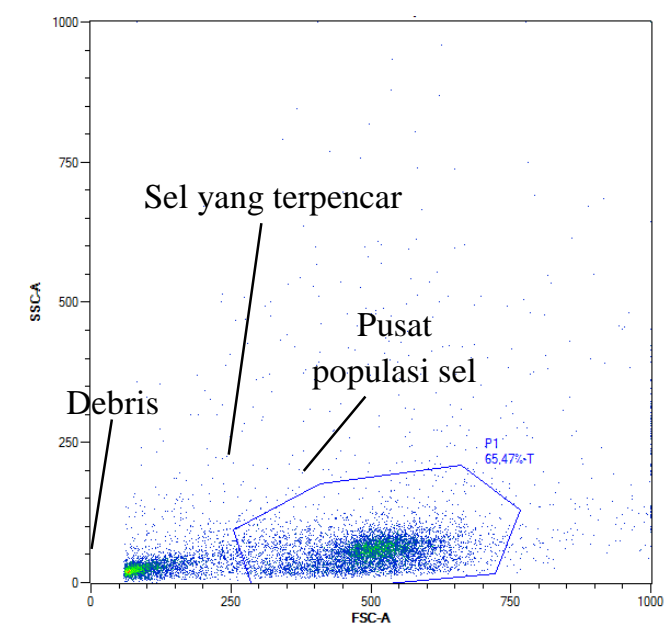

Gambar 2. Gating Cell Menggunakan Software MACS Quantify

Sel-sel yang memiliki karakteristik yang sama akan berkelompok bersama [23]. Selanjutnya, pada plot yang menampilkan dua parameter (two parameter dot plots), dihasilkan persentase populasi sel berdasarkan penanda yang diekspresikannya (Gambar 3). Two parameter dot plots menunjukkan dua parameter, yaitu fluorophores 1 pada sumbu $\mathrm{X}$ dan fluorophores 2 pada sumbu Y. Pada two parameter dot plots, dapat dilakukan identifikasi sel yang positif tunggal dan sel positif ganda [23].

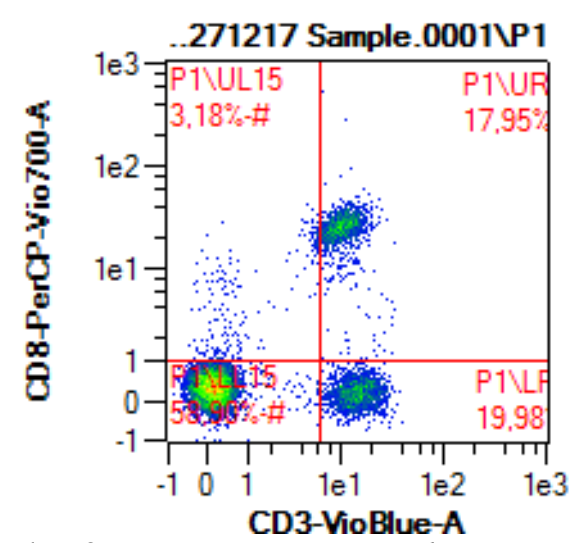

Gambar 3. Two Parameter Dot Plots Menggunakan Penanda CD3-VioBlue dan CD8-PerCP-Vio700

Pada two parameter dot plots, persentase populasi sel CD3 negatif dan CD8 negatif (CD3-/CD8-) berada di kiri bawah, sedangkan persentase sel CD3 negatif dan CD8 positif (CD3-/CD8+) berada di kiri atas. Persentase populasi sel CD3 positif dan CD8 positif (CD3+/CD8+) berada di kanan atas, sedangkan persentase sel CD3 positif dan CD8 negatif (CD3+/CD8-) berada di kanan bawah [24].

\section{Analisis Statistik}

Data yang telah dihasilkan dari analisis menggunakan software Macsquant 10 flow cytometer kemudian dianalisis menggunakan SPSS 21.0. Data tersebut terlebih dahulu diuji normalitasnya. Apabila nilai $\mathrm{P}$ yang dihasilkan > 0.05, artinya data berdistribusi normal, dan apabila nilai $\mathrm{P}$ yang dihasilkan $<0.05$, artinya data tidak berdistribusi normal.

Setelah uji normalitas, data dianalisis menggunakan uji korelasi bivariat Spearman apabila data tidak berdistribusi normal dan dianalisis menggunakan uji korelasi bivariat Pearson apabila data berdistribusi normal. Nilai $\mathrm{P}<0.05$ menunjukkan adanya korelasi yang bermakna. Tabel 1 merupakan kategori koefisien korelasi menurut [25].

Tabel 1. Kategori Koefisien Korelasi

\begin{tabular}{cc}
\hline Interval Koefisien & Tingkat Hubungan \\
\hline $0,00-0,199$ & Sangat Rendah \\
$0,20-0,399$ & Rendah \\
$0,40-0,599$ & Sedang \\
$0,60-0,799$ & Kuat \\
$0,80-1,000$ & Sangat Kuat \\
\hline
\end{tabular}


Uji korelasi bivariat Spearman maupun Pearson akan menghasilkan koefisien korelasi. Koefisien korelasi ini menunjukkan seberapa kuat hubungan yang terjalin antara faktor yang mempengaruhi dengan variabel.

\section{HASIL DAN PEMBAHASAN}

Sampel pada penelitian ini berjumlah 24 pasien Klinik Hayandra dengan proporsi sebanyak 0,92\% dari pasien perempuan dan sebanyak $0,08 \%$ dari pasien laki-laki, dengan kondisi klinis 22 pasien normal (sehat), 1 pasien mengidap penyakit myasthenia gravis dan vitiligo, dan 1 pasien mengidap penyakit tinitus. Rentang usia pasien adalah 19-84 tahun, dengan rata-rata usia pasien 41,17 tahun dan median usia pasien 40 tahun. Hasil analisis PBMC pasien menggunakan flow cytometry menunjukkan persentase sel limfosit $\mathrm{T}$, sel limfosit T sitotoksik, sel NK, sel NKT, dan sel NKT aktif yang berbeda-beda. Hal ini berarti bahwa profil PBMC yang dimiliki oleh masing-masing pasien berbeda. Salah satu faktor yang diduga mempengaruhi adanya perbedaan tersebut adalah usia. Oleh karena itu, dilakukan uji korelasi antara CD3+/CD19- dengan usia, CD3+/CD8+ dengan usia, CD3-/CD56+ dengan usia, CD3+/CD56+ dengan usia, dan $\mathrm{CD} 3+/ \mathrm{NKG} 2 \mathrm{D}+$ dengan usia.

\section{CD3+/CD19- dengan Usia}

CD3 merupakan penanda sel limfosit $T$ [12], sedangkan CD19 merupakan penanda sel limfosit B [13], sehingga dapat dikatakan bahwa persentase CD3+/CD19- menunjukkan persentase jumlah sel limfosit $\mathrm{T}$ yang ada dalam tubuh pasien. Berikut ini hasil uji korelasi sel imun terhadap usia.

Tabel 2. Hasil Uji Korelasi Sel Imun dengan Usia

\begin{tabular}{cccc}
\hline & $\begin{array}{c}\text { Koefisien } \\
\text { Korelasi }(\mathbf{r})\end{array}$ & $\begin{array}{c}\text { Kategori } \\
\text { Korelasi }\end{array}$ & $\begin{array}{c}\text { Nilai } \\
\mathbf{P}\end{array}$ \\
\hline CD3+/CD19- & $-0,298$ & Rendah & 0,57 \\
CD3+/CD8+ & $\mathbf{- 0 , 5 1 6}$ & Sedang & $\mathbf{0 , 0 1}$ \\
CD3-/CD56+ & 0,196 & Rendah & 0,359 \\
CD3+/CD56+ & $\mathbf{0 , 4 3 7}$ & Sedang & $\mathbf{0 , 0 3 3}$ \\
CD3+/NKG2D+ & $-0,04$ & $\begin{array}{c}\text { Sangat } \\
\text { Rendah }\end{array}$ & 0,853 \\
\hline
\end{tabular}

Berdasarkan Tabel 2, dapat diketahui bahwa nilai $\mathrm{P}$ untuk korelasi antara persentase CD3+/CD19dengan usia adalah lebih besar dari 0,05. Hal ini menunjukkan bahwa tidak terdapat korelasi yang bermakna antara persentase CD3+/CD19- dengan usia, artinya persentase jumlah sel limfosit $\mathrm{T}$ pada pasien tidak dipengaruhi oleh usia. Temuan tersebut tidak sejalan dengan penelitian [1], yang menyatakan bahwa bertambahnya usia dapat mempengaruhi fungsi dan jumlah sel limfosit $\mathrm{T}$ dalam tubuh manusia.

Bertambahnya usia juga dapat menyebabkan sel limfosit $\mathrm{T}$ menjadi hiporesponsif atau kurang dapat merespon adanya antigen [1]. Menurut [26], menurunnya fungsi dan jumlah sel limfosit $\mathrm{T}$ dapat berpengaruh pada fungsi sel limfosit B. Antigen selalu mengaktivasi sel limfosit $\mathrm{T}$ terlebih dahulu ketika antigen akan merangsang respon imun spesifik. Setelah sel limfosit $\mathrm{T}$ aktif, sel limfosit $\mathrm{T}$ akan melawan antigen dan merangsang aktivasi sel limfosit B. Setelah sel limfosit B aktif, sel limfosit B akan merangsang pembentukan antibodi untuk melawan antigen tersebut [1]. Namun, apabila fungsi dan jumlah sel limfosit $\mathrm{T}$ menurun, maka akan semakin sedikit juga jumlah sel limfosit $\mathrm{T}$ yang dapat melawan antigen dan merangsang aktivasi sel limfosit B serta akan terjadi penurunan kemampuan sel limfosit $\mathrm{T}$ dalam melawan antigen dan merangsang aktivasi sel limfosit B. Hal ini menyebabkan kemampuan tubuh saat usia lanjut dalam mengontrol dan melawan serangan penyakit menjadi berkurang dibandingkan dengan saat usia muda [26].

\section{CD3+/CD8+ dengan Usia}

CD3 merupakan penanda sel limfosit $\mathrm{T}$, sedangkan CD8 merupakan penanda sel limfosit $\mathrm{T}$ sitotoksik [12], sehingga dapat dikatakan bahwa persentase CD3+/CD8+ menunjukkan persentase jumlah sel limfosit $\mathrm{T}$ sitotoksik yang ada dalam tubuh pasien. Berdasarkan Tabel 2, dapat diketahui bahwa nilai $\mathrm{P}$ untuk korelasi antara persentase CD3+/CD8+ dengan usia adalah lebih kecil dari 0,05 . Hal ini menunjukkan bahwa terdapat korelasi yang bermakna antara persentase CD3+/CD8+ dengan usia, artinya persentase jumlah sel limfosit $\mathrm{T}$ sitotoksik pada pasien dipengaruhi oleh usia. Persentase CD3+/CD8+ memiliki korelasi yang negatif dengan usia, dengan nilai koefisien korelasi yang tergolong sedang, yaitu $-0,516$. Berdasarkan korelasi tersebut, dapat diketahui bahwa semakin bertambahnya usia seseorang (semakin tua) maka semakin kecil persentase $\mathrm{CD} 3+/ \mathrm{CD} 8+$ yang dihasilkan atau semakin sedikit jumlah sel limfosit T sitotoksik yang ada dalam tubuh pasien. Hal ini sesuai dengan penelitian [26], yang menyatakan bahwa di dalam tubuh manusia terdapat sel limfosit $\mathrm{T}$ yang jumlahnya banyak, namun jumlah sel limfosit T, khususnya sel limfosit T sitotoksik akan berkurang seiring dengan bertambahnya usia. Saat 
usia lanjut, kemampuan tubuh dalam mengontrol penyakit menjadi berkurang dibandingkan dengan saat usia muda [26].

Sel limfosit $\mathrm{T}$ sitotoksik merupakan sel yang berperan dalam mengenali dan merusak sel yang terinfeksi atau sel yang abnormal. Selain itu, sel limfosit $\mathrm{T}$ sitotoksik juga dapat menekan aktivitas sel darah putih yang lain dengan tujuan sebagai perlindungan untuk jaringan normal [26]. Apabila jumlah sel limfosit $\mathrm{T}$ sitotoksik berkurang, maka akan semakin sedikit juga jumlah sel limfosit $\mathrm{T}$ sitotoksik yang melawan atau merusak sel yang terinfeksi [1]. Hal ini yang menyebabkan manusia yang berusia lanjut lebih rentan terserang penyakit. Selain itu, kemampuan tubuh dalam mengontrol penyakit juga menjadi berkurang dibandingkan dengan saat usia muda [26].

\section{CD3-/CD56+ dengan Usia}

CD3 merupakan penanda sel limfosit $\mathrm{T}$ [12], sedangkan CD56 merupakan penanda sel NK [14]. CD3-/CD56+ bukan merupakan sel NKT, melainkan merupakan sel NK. Sel NKT hanya dapat mengekspresikan penanda CD56 bersamaan dengan CD3 (CD3+/CD56+) [27] sehingga dapat dikatakan bahwa persentase CD3-/CD56+ menunjukkan persentase jumlah sel NK yang ada dalam tubuh pasien. Berdasarkan Tabel 2, dapat diketahui bahwa nilai $\mathrm{P}$ untuk korelasi antara persentase CD3/CD56+ dengan usia adalah lebih besar dari 0,05. $\mathrm{Hal}$ ini menunjukkan bahwa tidak terdapat korelasi yang bermakna antara persentase CD3-/CD56+ dengan usia, artinya persentase jumlah sel NK pada pasien tidak dipengaruhi oleh usia. Hasil penelitian ini bertentangan dengan penelitian [28], yang menemukan terjadinya peningkatan yang signifikan pada persentase jumlah sel NK (CD3-/CD56+) seiring bertambahnya usia. Hal yang menarik adalah berdasarkan hasil penelitian [29], diketahui bahwa orang yang memiliki jumlah sel NK sedikit memiliki risiko kematian tiga kali lebih tinggi dibandingkan dengan orang yang memiliki jumlah sel NK banyak. Berdasarkan hal tersebut, maka dapat dikatakan bahwa peningkatan persentase jumlah sel NK seiring bertambahnya usia ini dapat menjadi salah satu faktor yang menyebabkan panjangnya umur seseorang [28].

\section{CD3+/CD56+ dengan Usia}

CD3 merupakan penanda sel limfosit $\mathrm{T}$ [12], sedangkan CD56 merupakan penanda sel NK [14], sehingga dapat dikatakan bahwa persentase CD3+/CD56+ menunjukkan persentase jumlah sel NKT yang ada dalam tubuh pasien. Sel NKT adalah sel limfosit $\mathrm{T}$ yang mengekspresikan penanda sel NK [30]. Sel NKT bukan merupakan sel NK, melainkan adalah sub-populasi kecil yang unik dari sel $\mathrm{T}$ yang sebenarnya. Sel NKT memegang peran utama dalam mengatur respon imun dengan menjembatani sistem imun bawaan dan sistem imun adaptif. Sel NKT memiliki reseptor sel T ( $T$ Cell Receptor/TCR) antigen spesifik yang memungkinkan sel NKT untuk dapat mengenali antigen dirinya dan antigen asing. Hal ini yang menyebabkan sel $\mathrm{T}$ dapat mengekspresikan penanda sel NK. Sel NKT juga berperan dalam sistem kekebalan tubuh, yaitu dalam mendeteksi antigen lipid yang tidak terdeteksi oleh sel $\mathrm{T}$ konvensional [31]. Berdasarkan Tabel 2, dapat diketahui bahwa nilai $P$ untuk korelasi antara persentase CD3+/CD56+ dengan usia adalah lebih kecil dari 0,05 . Hal ini menunjukkan bahwa terdapat korelasi yang bermakna antara persentase CD3+/CD56+ dengan usia, artinya persentase jumlah sel NKT pada pasien dipengaruhi oleh usia. Menurut [32], sel NKT merupakan sel imun yang paling dipengaruhi oleh usia. Pada penelitian ini, persentase CD3+/CD56+ memiliki korelasi yang positif dengan usia, dengan nilai koefisien korelasi yang tergolong sedang, yaitu sebesar 0,437. Berdasarkan korelasi tersebut, dapat diketahui bahwa semakin bertambahnya usia seseorang (semakin tua) maka semakin besar juga persentase CD3+/CD56+ yang dihasilkan atau semakin banyak jumlah sel NKT yang ada dalam tubuh pasien. Hal ini sesuai dengan hasil penelitian [33] [34], yang menemukan terjadinya peningkatan jumlah sel NKT (CD3+/CD56+) seiring bertambahnya usia.

\section{CD3+/NKG2D+ dengan Usia}

CD3 merupakan penanda sel limfosit $T$ [12], sedangkan NKG2D+ merupakan reseptor yang mengaktivasi sel NK [25] dan merupakan penanda sel NK yang aktif, sehingga dapat dikatakan bahwa persentase $\mathrm{CD} 3+/ \mathrm{NKG} 2 \mathrm{D}+$ menunjukkan persentase jumlah sel NKT yang aktif dalam tubuh pasien. Berdasarkan Tabel 2, dapat diketahui bahwa nilai $P$ untuk korelasi antara persentase $\mathrm{CD} 3+/ \mathrm{NKG} 2 \mathrm{D}+$ dengan usia adalah lebih besar dari 0,05 . Hal ini menunjukkan bahwa tidak terdapat korelasi yang bermakna antara persentase CD3+/NKG2D+ dengan usia, artinya persentase jumlah sel NKT yang aktif pada pasien tidak dipengaruhi oleh usia.

Terkait dengan korelasi antara jumlah sel NKT yang aktif (CD3+/NKG2D+) dengan usia, belum dapat dijelaskan secara utuh. Namun demikian korelasi antara jumlah sel NKT yang aktif (CD3+/NKG2D+) 
dengan penyakit salah satunya adalah metastasis kanker kolorektal telah ditemukan oleh [35]. Pada penelitian tersebut, [35] menemukan bahwa jumlah sel NKT yang aktif secara signifikan lebih rendah pada pasien yang mengidap penyakit kanker kolorektal metastasis dibandingkan dengan yang tidak mengidap penyakit tersebut (sehat). Di samping itu penentuan profil sel dengan penanda tertentu juga dapat membantu justifikasi marker yang tepat terutama ketika proses yang diinginkan adalah adanya diferensiasi stem cell menjadi tipe sel tertentu misalnya embryonic stem cell menjadi sel neuron [36].

\section{KESIMPULAN DAN SARAN}

\section{Kesimpulan}

1. Profil PBMC pasien di Klinik Hayandra terdiri atas sel limfosit T, sel limfosit T sitotoksik, sel NK, sel NKT, dan sel NKT yang aktif.

2. Sel imun pasien ada kaitannya dengan usia pasien.

3. Usia pasien mempengaruhi jumlah sel imun yang dimiliki.

4. Penentuan profil PBMC menggunakan flow cytometry dapat memberikan hasil yang baik.

\section{Saran}

Pada penelitian ini, tidak dilakukan pengkategorian usia dalam mengkorelasikan usia dengan profil PBMC. Sebaiknya dalam penelitian selanjutnya dilakukan pengkategorian usia terlebih dahulu, sehingga dapat diketahui secara jelas bagaimana tingkatan usia seseorang dalam mempengaruhi profil PBMC yang dimilikinya.

\section{DAFTAR PUSTAKA}

[1] Y. Arina, "Pengaruh Aging Terhadap Sistem Imun," JKM, vol. 3, no. 1, pp. 53-57, 2003.

[2] Zenbio, "Peripheral Blood Mononuclear Cells (PBMCs)," ZenBio, Inc, 2016. [Online]. Available: $\quad$ http://www.zenbio.com/products/cells/pbmcs.php. [Diakses pada 1 Februari 2018].

[3] S. E, Anatomi dan Fisiologi untuk Pemula, Jakarta: Penerbit Buku Kedokteran EGC, 2004.

[4] R. Lane, "Four Downstream Applications for Isolated Peripheral Blood Mononuclear Cells," Folio Conversant, 2014 November 2014.
[Online].

Available:https://www.dls.com/biopharma/blo g/4-downstream-applications-of-pbmcisolation-from-whole-blood. [Diakses pada 15 Maret 2018].

[5] A. Unitly and D. Sahertian, "Deteksi Kandungan Antioksidan Superoksida Dismutase (SOD) pada Organ Ginjal Tikus Ratus Norvegicus Dengan Pewarnaan Imunohistokimia," in Seminar Nasional Basic Science II, Malang, 2010.

[6] T. Sun, Flow Cytometry, Immunohistochemistry, and Molecular Genetics for Hematologic Neoplasms Second Editions, USA: Lippincott Williams dan Wilkins, 2012.

[7] I. U. S, T. Teguh and B. Mulyono, "Aplikasi Flow Cytometry di Laboratorium," Berkala Kesehatan Klinik, no. 2, pp. 115-125, 2003.

[8] F. Nathalia, "Perbandingan Nilai Hematologi Antara Medical Check Up (MCU) di Rumah Sakit Puri Medika Jakarta dengan Nilai Rujukan alat Sysmex XS-800i.[thesis]," Universitas Kristen Maranatha, Bandung, 2014.

[9] N. Brown and C. Wittwer, "Flow cytometry: principles and clinical applications in hematology.," Clin Chem, vol. 46, no. 2, pp. 1221-1229, 2000.

[10] R. Robinson and S. Pellenz, "What is flow cytometry (FACS analysis)?," antibodies online.com, 12 juni 2013. [Online]. Available: https://www.antibodiesonline.com/resources/17/1247/what-is-flowcytometry-facs-analysis/. [Diakses 2018 April $01]$.

[11] J. Segen, Concise dictinory of, New York: The Mc Graw-Hill Companies, Inc, 2002.

[12] W. Sandhika, R. M. Novarina and T. Setyaningrum, "Pemeriksaan Imunohistokimia untuk Mengungkap Patogenesis Vitiligo," CDK-245, vol. 43, no. 10, pp. 742-746, 2016.

[13] K. Wang, G. Wei and a. D. Liu, "CD19: a biomarker for B cell development, lymphoma diagnosis and therapy.," Hematol Oncol, vol. 1, no. 36, 2012.

[14] F. Naeim, P. Rao, S. Song and R. Phan, Atlas of Hematopathology, Tokyo: Academic Press, 2013.

[15] D. E. Meyers, S. Thakur, C. M. Thirukkumaran and D. G. Morris, "Oncolytic virotherapy as an immunotherapeutic strategy 
for multiple myeloma," Blood Cancer Journal, vol. 7, no. 12, 2017.

[16] Y. Jing, S. Gravenstein, N. Chaganty, N. Chen, K. Lyerly, S. Joyce and Y. Deng, "Aging is associated with a rapid decline in frequency, alterations in subset composition, and enhanced Th2 response in CD1d-restricted NKT cells from human peripheral blood.," Exp Gerontol, vol. 42, no. 8, pp. 719-732, 2007.

[17] C. Corkum, D. Ings, C. Burgess, S. Karwowska, W. Kroll and T. Michalak, "Immune cell subsets and their gene expression profiles from human PBMC isolated by Vacutainer Cell Preparation Tube $\left(\mathrm{CPT}^{\mathrm{TM}}\right)$ and standard density gradient.," $B M C$ Immonual, vol. 16, no. 48, 2015.

[18] L. Doiron, "5 Types of Mononuclear Cells and How They Differ," Folio Conversant, 10 May 2016. [Online]. Available: https://www.dls.com/biopharma/blog/5-typesof-mononuclear-cells-and-how-they-differ. [Diakses pada 24 Februari 2018].

[19] C. R. Kleiveland, "Peripheral Blood Mononuclear Cells," in The Impact of Food Bioactives on Health: in vitro and ex vivo models , US, National Library of Medcine, 2015, pp. 161-167.

[20] L. Doiran, "3 Reasons Whole Blood is Necessary for PBMC Isolation," Folio Conversant, 31 Maret 2015. [Online]. Available: http:www.conversantbio.com/blog/ 3-reasonswhole-blood-is-necessaryforpbmcisolation/. [Diakses pada 06 Mei 2018].

[21] H. Putri, "Preparasi Sampel Untuk Siklus Sel Dengan Metode Flowcytometry," Fakultas Farmasi UGM, Yogyakarta, 2014.

[22] E. O'Donnell, D. Ernst and R. Hingorani, "Multiparameter Flow Cytometry: Advances in High Resolution Analysis," Imune Network, vol. 13, pp. 43-54, 2013.

[23] Bio-Rad Laboratories, "Data Analysis in Flow Cytometry," Bio- Rad Laboratories, 2016. [Online]. Available: https;//www.bioradantibodies.com/flow-cytometry-gatingstrategies.html. [Diakses pada 11 April 2018].

[24] C. Paul, "An Introduction to Gating in Flow Cytometry," Bitesize Bio, 2015. [Online].Available:https://bitesizebio.com/21 596/an-introduction-to-gating-in-flowcytometry/. [Diakses pada 11 April 2018].
[25] Sugiyono, Metode Penelitian Pendidikan Pendekatan Kuantitatif, Kualitatif , dan R\&D, Bandung: Alfabeta, 2014.

[26] Fatmah, "Respons Imunitas yang Rendah pada Tubuh Manusia Usia Lanjut," Makara Kesehatan, vol. 10, no. 1, pp. 48-50, 2006.

[27] Andrea, "Natural Killer Cell subtypes and markers in human PBMC," PBMC Basics, 14 Maret 2013. [Online]. Available:https://technical.sanguinebio.com/n atural-killer-cell-subtypes-and-markers-inhuman-pbmc/. [Diakses pada 24 February 2018].

[28] M. L. Garff-Tavernier, V. Beziat, DecocaJ, V. Siguret, F. Gandibakhch, E. Pautas, P. Debre, H. Merle-Beral and Vieillard, "Human NK cells display major phenotypic and functional changes over the life span," Aging Cell, vol. 9, no. 4, pp. 527-535, 2010.

[29] E. P. Remarque, "T cell immunosenescence and its clinical relevance in man," Rev. Clin. Gerontology, vol. 8, pp. 5-14, 1998.

[30] Y. Jiang, X. Cui, C. Cui, J. Zhang, F. Zhou, Z. Zhang, Y. Fu, J. Xu, Z. Chu, J. Liu, X. Han, C. Liao, Y. Wang, Y. Cao and H. Shang, "The Function of CD3+CD56+ NKT-Like Cells in HIV-Infected Individuals," Biomed Res Int, no. 863625, 2014.

[31] B. J. Terabe M, "The role of NKT cells in tumor immunity.," Adv Cancer Res, no. 101, pp. 277-348, 2008.

[32] Y. Chen and H. Liao, "NK/NKT Cells And Aging," Internasional Journal of Gerontology, vol. 1, no. 2, pp. 65-69, 2007.

[33] P. Sansoni, A. Cossariza, V. Brianti, F. Fagnoni, G. Sneli, D. Monti, A. Marcato, G. Passeri, C. Ortalani, E. Forti, U. Fagiolo, M. Passed and C. Franceschi, "Lymphocyte subsets and natural killer cell activity in healthy old people and centenarians," Blood 82, no. 2767-2773, 1993.

[34] S. M. Nerlans, I. Ria, H. Alexander and T. Moris, "Changes in natural killer cells, the CD57CD8 subset, and realted cytokines in healthy aging," J. Clin Immunol, no. 18, pp. 31-38, 1998.

[35] M. Gharagozolo, A. Rezai, H. Kalantari, A. Bahador, N. HAssannejad, M. Maracy, N. Noury, M. Sedghi, H. Ghazanfari and B. Bayat, "Decline in peripheral blood NKG2D+CD 3+CD 56+ NKT cells in 
colorectal cancer patient," Bratislava Medical Journal, vol. 119, no. 1, pp. 6-11, 2018.

[36] R. L. Puspitasari, A. Boediono and F. Sandra, "Conditioned medium dari kultur primer sel syaraf Mus musculus," in Seminar Nasional X Pendidikan Biologi FKIP UNS, Solo, 2013.

[37] S. JC, Concise dictionary of modern medcine, New York: The McGraw-Hill Companies, 2002.
[38] Mendez-David, Z. El-Ali, R. Hen, B. Fallissard and E. Corruble, "A method for biomarker measurements in peripheral blood mononuclear cells isolated from anxious and depressed mice: $\beta$-arrestin 1 protein levels in depression and treatment.," Front Pharmacol, vol. 4, no. 124, 2013. 